\title{
NĚMECKÁ PŘÍJMENÍ V PŘÍHRANIČNÍ OBLASTI JIŽNÍCH ČECH A JEJICH SÉMANTICKO-MOTIVAČNÍ TYPY
}

\author{
Alena Jaklová \\ Jihočeská univerzita v Českých Budějovicích, \\ Filozofická fakulta, Ústav česko-německých areálových studií a germanistiky, \\ Branišovská 31a, 37005 České Budějovice, Česká republika \\ e-mail: jaklova@ff.jcu.cz
}

\begin{abstract}
Abstrakt
Obsahem článku jsou analýzy německých příjmení z aspektu motivačního a klasifikace těchto př́ijmení do sémanticko-motivačních typů. Východiskem analýz je materiálový korpus, který byl vytvořen na počátku 21. století na základě studia archivních materiálů zaznamenávajících př́ijmení občanů z obcí Prachatice, Volary, Vimperk a Kašperské Hory. Jde o města ležící v blízkosti hranic s Německem, města, která byla až do poloviny čtyřicátých let 20. sto-letí osídlena převážně německým obyvatelstvem. V závěru článku jsou stanoveny nejfrekventovanější sémanticko-motivační typy současných německých př́ijmení u Čechů užívaných ve zkoumaném areálu. Zároveň je objasněna etymologie a motivace těchto jmen jejich vztahem k historii regionu a k etnikům, která již od středověku tento areál obývala.
\end{abstract}

\section{Keywords}

German surnames; Semantic-motivational types; South-Bohemian borderland; Early $21^{\text {st }}$ century.

\section{Úvod}

Tématem této studie jsou př́ijmení německého původu užívaná v současnosti v příhraniční oblasti jižních Čech a jejich sémanticko-motivační typy. Zkoumání sémanticko-motivačních typů př́jmení umožňuje zamýšlet se nad sémantickou motivací těchto jmen ve vztahu $\mathrm{k}$ historii regionu a k etnikům, která již od středověku tento areál obývala.

Německá př́ijmení uživaná v České republice jsou důsledkem přímých kontaktů mezi českým a německým etnikem, které trvaly staletí. Němečtí přistěhovalci přicházeli do Čech už od konce 12. století. O původu těch, kteří se usazovali v českém příhraničí, existují odlišné názory. Podle některých autorů osídlili nejjižnější část Šumavy, kam náleží i Prachaticko a Volarsko, valdenští ze sousedních Bavor a Horních Rakous, kde měli statky také Rožmberkové. [1: 2] Podle jiných autorů [2: 10] přicházeli přistěhovalci až z oblastí při Dunaji, nebot' i bavorská část hraničního hvozdu byla tehdy stejně jako česká neobydleným pralesem. Německá nářečí na Šumavě proto nebyla přimým pokračováním nářečního pásu sousedních zemí. Na Šumavě se nářečí skupin osad, a dokonce i jednotlivých sousedních obcí od sebe velmi lišila. To dokazuje, že přistěhovalci nepřicházeli z jediné oblasti. [3: 29]

Na jižní části Šumavy se mluvilo nářečím středobavorským. Lze tedy předpokládat, že tamní Němci se do této oblasti přistěhovali z přilehlých území, tj. z Horních Rakous a z Bavorského lesa. To potvrzuje i E. Schwarz, který ve své práci z roku 1934 píše: „Protože se jižně od Šumavy kolonizovalo dřvive než na sever od zalesněného pohoří, vyšlo německé osídlení jižních Čech z Horních Rakous a Bavorského lesa “. [4: 551] 
V jižních Čechách byla tato česko-německá kontaktní situace umocněna existencí Zlaté stezky, nejvýznamnější středověké komunikace, která od počátku 11. století spojovala v jedné své větvi Pasov s Prachaticemi. ${ }^{1}$ Svou roli až do doby po druhé světové válce sehrálo také hojné osídlení českého př́hraničního regionu, tzv. Sudet, německým obyvatelstvem, které zde žilo od 13. století a které běžně přicházelo do styku s obyvatelstvem českým. Jedním $\mathrm{z}$ dokladů po staletí trvající koexistence českého a německého obyvatelstva $\mathrm{v}$ jižních Čechách je i dnes vyšší frekvence německých př́jmení na tomto území ve srovnání s výskytem př́ijmení německého původu, která jsou dnes užívána na celém území České republiky. [5]

Čeština a němčina se na základě dlouhodobého kontaktu navzájem ovlivňovaly. To se $\mathrm{v}$ češtině projevovalo v rovině fonologické, morfologické, syntaktické i lexikální. [6] Jednalo se zejména o přejímání slov, výpůjčky a kalky, a také o zvýšenou frekvenci německých vlastních jmen, konkrétně o německá př́immení, německá jména místní a německá jména pomístní.

\section{$1 \quad$ Aplikovaná metodologie, materiálový korpus}

Př́ijmení lze zhlediska lingvistického zkoumat $\mathrm{z}$ rozmanitých aspektů. Je to aspekt etymologický, motivační, slovotvorný, gramatický, pravopisný a frekvenční. Výsledky zkoumání ze všech těchto aspektů pak mohou podat komplexní charakteristiku systému př́ijmení užívaných na území jednoho národního jazyka. [7]

V této studii se zabýváme zkoumáním př́imení z aspektu motivačního. Zjišt'ovat sémantickou motivaci vzniku př́ijmení znamená uvažovat i o vlastnostech prvního nositele př́jmení a o historických, společenských, národnostních a jazykových poměrech doby, kdy jméno vzniklo. [8]

Klasifikace typů př́ijmení podle motivace jejich vzniku není v odborné literatuře jednotná, př́ijmení klasifikují různě i čeští a němečtí lingvisté. V české odborné literatuře se touto problematikou zabývají zejména Josef Beneš [3], Miloslava Knappová [8], Dobrava Moldanová [9], a Jana Matúšová [10].

V následujícím textu vycházíme z klasifikace typů př́ijmení zpracované J. Benešem [5: 59355]. Benešova dvousvazková monografie Německá př́imení u Čechů respektuje lingvistická specifika němčiny a zároveň se nám jeho členění př́ijmení se svými podtypy jeví jako přehledné a detailní. Výsledky svého zkoumání dále doplňujeme či konfrontujeme s údaji v monografiích německých a rakouských autorů. Jde zejména o práce: E. Schwarze [4], [11], R. Kohlheimové \& V. Kohlheima [12], M. Gottschalda [13], M. Hornungové [14], K. Kunze [15] a H. Klausmanna [16].

V našich analýzách vycházíme z rozsáhlého materiálu, který jsme získali studiem archivních dokumentů v průběhu řešení Programu přeshraniční spolupráce Česká republika - Svobodný stát Bavorsko, Cíl EÚS 2014-2020. Projekt nesl název "Aus der Tradition in die Zukunft. Das sprachlich-literarische Erbe Ostbayerns und Südböhmens als Fokus universitärer Zusammenarbeit / Od tradice $k$ budoucnosti. Jazykově-literární dědictví Východního Bavorska a jižních Čech jako fokus univerzitní spolupráce" a byl řešen v letech 2016-2019 akademickými pracovníky Jihočeské univerzity v Českých Budějovicích a Univerzity Pasov.

Základem sémanticko-motivačních analýz je rozsáhlý materiálový korpus ${ }^{2}$ obsahující celkem 6237 německých příjmení užívaných českými občany žijícími v současné době v obcích

\footnotetext{
${ }^{1}$ Provoz na Zlaté stezce zanikl počátkem 18. století.

${ }^{2} \mathrm{O}$ tvorbě materiálového korpusu současných německých příjmení užívaných Čechy v příhraniční oblasti jižních Čech a jeho obsahu viz blíže A. Jaklová [1].
} 
Prachatice, Volary, Vimperk a Kašperské Hory. ${ }^{3}$ Jde o města ležící v blízkosti hranic s Německem, města, která byla až do poloviny čtyřicátých let 20 . století osídlena převážně německým obyvatelstvem. V minulosti vedly těmito městy také jednotlivé větve dávné obchodní komunikace Zlaté stezky. Ta zajišt'ovala nejen výměnu zboží, ale také pravidelný kontakt českého a německého etnika.

Z rozsáhlého materiálu, který jsme získali studiem archivních dat, jsme za základ našich analýz z aspektu motivačního zvolili náhodný vzorek 356 německých př́ijmení, která označují celkem 1420 obyvatel. Jsou to čeští občané žijící hlavně v Prachaticích, bývalém významném středisku ležícím na Zlaté stezce a později převážně německém městě. Tento základní korpus jmen jsme doplnili i o německá př́íjmení užívaná dnes občany Volar, Vimperka a Kašperských Hor.

\section{Nejfrekventovanější sémanticko-motivační typy německých příjmení užívaných v př́íhraniční oblasti jižních Čech}

Jak je patrné z následujícího přehledu, lze na základě výzkumů v př́hraniční oblasti jižních Čech považovat četnost výskytu německých př́ijmení náležejících k jednotlivým sémantickomotivačním typům za areálově podmíněnou.

a) Nejpočetněji zastoupená německá př́ijmení zaznamenaná v našem materiálu byla utvořena z toponym (vlastních jmen zeměpisných) a jiných vlastních jmen. Př́značné přitom je, že jde o vlastní jména míst nacházejících se v naprosto převažující míre v Bavorsku, méně často také v Rakousku, tzn. na území, $\mathrm{z}$ něhož na Šumavu a do jižních Čech s největší pravděpodobností předkové sudetských ${ }^{4}$ Němců kdysi přišli.

Vyjdeme-li z klasifikace německých př́ijmení podle aspektu motivačního uváděné v práci J. Beneše [3: 145-354], jde např́klad o tato jména:

Blumauer - příjmení vyjadřující původ ze jména místního Blumau vyskytujícího se v Bavorsku a Rakousku

Bruckner/Brukner - příjmení z místního jména Bruckner užívaného v Dolním Rakousku a Horním Bavorsku

Dörfler - př́imení z místního jména Dörfel běžného v Rakousku, Horním Bavorsku a v Dolním Bavorsku

Fakenberg - př́ijmení z místního jména na územích obývaných Němci: Fachenberg v Horním Bavorsku, Fachberg v Horním Rakousku

Fellner, Felner - př́jmení ze jmen místních na území obývaných Němci: Felden, Velden v Bavorsku i Rakousku [12: 239]

Pisinger, Pizingr - příjmení z místního jména Piesing v Horním Bavorsku

Bernkopf - př́íjmení z místních jmen na území Rakouska: z Bärnkopf v Dolním Rakousku

Brandl - př́jimení z místního jména na ostatních územích obývaných Němci, konkrétně z místního jména Brandl v Horním Bavorsku a Dolním Bavorsku

\footnotetext{
${ }^{3}$ Výskyt současných německých př́ijmení v obcích Vimperk a Kašperské Hory byl zkoumán mimo rámec řešení projektu.

${ }^{4}$ Výraz Sudety (v odborné literatuře také pohraničí, pohraniční území, pohraniční oblasti nebo smišsené územi) označuje teritoria, na nichž v ČSR sídlilo převážně německé obyvatelstvo. Toto území tvořilo místy až $100 \mathrm{~km}$ široký pás kolem jádra českých zemí. Po skončení druhé světové války v roce 1945 byly Sudety v důsledku vynuceného odchodu původních německých obyvatel a prríchodu novoosídlenců ve zvýšené míře zasaženy sídelními přesuny.
} 
Eichner - př́ijmení místního jména Eichen nebo Aichen či Eichenau; tato jména se vyskytují v Horním Bavorsku a Dolním Rakousku

Gaier, Geier, Kajer - příjmení z místních jmen na území Saska: Geyer v Krušných horách, nebo Geier v Horním Bavorsku, nebo Geyer v Dolním Rakousku, nebo Geyer = sup, dravý pták

Kreiner - př́jmení z místních jmen Kreina, Krein vyskytujících se v Bavorsku, Horním Rakousku a Sasku

Sebera - př́imení z německých a rakouských jmen místních: Seeb v Bavorsku, Seeba v Durinsku a Seeben v Rakousku

Zaunmüller - př́ijmení z místních jmen na různých územích obývaných Němci: z Zaunmühle u Chvalšin, Českého Krumlova, Horní Plané, Volar, dále v Dolním Bavorsku a Dolním Rakousku

Stejnou motivaci má i řada dalších př́ijmení zaznamenaných v našem materiálovém korpusovém, např́klad Attendorn, Breit, Eisenhammer, Grillinger, Grabmüller, Grubner, Hagara, Herfurt, Hopfinger, Kasl, Kassl, Kasal, Nachlinger, Náchlinger, Nahlinger, Penc, Penz, Stifter, Štádler, Štambachský, Štamberský, Tušl, Wimberský, Zaunmüller, Zitta/Zita a řada dalších.

Menší podskupinu těchto jmen přestavují také příjmení utvořená z etnonym (vlastní jméno kmene nebo národa), názvů krajin, zemí a států. V našem materiálu jde vždy jen o pojmenování obyvatel Čech nebo Bavorska:

Baier, Beyer - z označení obyvatel Bavorska: Bayer

Beer - z označení obyvatel Bavorska (nebo z apelativ vztahujících se k přírodě, konkrétně $\mathrm{z}$ názvů šelem: střhněm. $b \ddot{e} r=$ medvěd, nebo $\mathrm{z}$ názvů lesních plodů: střhněm. $b e r=$ jahoda, bobule, či z názvi̊ nástrojůn, konkr. z názvů pomůcek $\mathrm{k}$ lovu: střhněm. bêre, bêr $=$ pytlovitá sít' na ryby, patrně čeřen)

Böhm - př́ijmení z označení obyvatel Čech - der Böhme

Binka - př́jmení z označení obyvatel Čech, provedena bavorská nářeční změna $\ddot{o}>i$ a dále záměna souhláskových skupin $m k / n k+$ koncovka - $a$

V analyzovaných materiálech jsme zaznamenali rovněž obsáhlou podskupinu př́ijmení utvořených ze jmen pomístních a obecných jmen zeměpisných, ve stručnosti např́iklad:

- př́ijmení z obecných jmen pomístních, např́íklad Krejsa/Krejza ze střdněm. kreis = kruh, okolí, hranice < střhněm. kreiz = kruh, okolí, území, oblast [12: 400] + česká koncovka $-a$.

- př́ijmení utvořená $\mathbf{z}$ hydronym (vlastní jména vod, tj. jména moří, zálivů, jezer, bažin, rybníků atd.), např. Brinke $-\mathrm{z}$ Brink = travnatý svah, vlhké místo.

- př́jmení z pojmenování pastvin, např́klad Blumentritt z trit $=\mathrm{mj}$. cesta, Blum = pastvina

- prř́jmení z pojmenování selských dvorců a samot, například Eder - př́ijmení ze jmen samot odvozené př́ponou -er: ze jména místního Oed užívaného v Horním Bavorsku, Dolním Bavorsko a v Rakousku.

- př́íjmení utvořená z oronym (vlastní jména tvarů vertikální členitosti zemského povrchu i mořského dna). Sem lze zařadit např́klad př́ijmení Gruber z názvů prohlubenin; např. Grube = hluboké údolí nebo př́ijmení Rangl z názvů vyvýšenin: Rang = svah kopce.

Motivaci a způsob tvoření těchto př́ijmení lze však za areálově podmíněné považovat pouze v ojedinělých př́ípadech (např. Eder). 
b) Naopak za areálově př́iznaková lze považovat německá prŕímení utvořená $\mathbf{z}$ apelativ a motivovaná názvy povolání, řemesel a řemeslníků. Často přitom jde o povolání nebo řemesla zabývající se prací se dřevem, tedy činností, která byla typická pro obyvatele Šumavy a Bavorského lesa. Takovými jmény jsou např́klad:

Bína - z názvů řemeslníků pracujících se dřevem: Binder = bednář

Bínek - počeštěné: česká deminutivní přípona $-e k<$ Bína $<\mathrm{z}$ názvů řemeslníků pracujících se dřevem: Binder = bednár̆

Binder - z názvů řemeslníků pracujících se dřevem: Binder = bednář

Dresler - z názvů řemeslníků pracujících se dřevem: Dreschler $=$ výrobce cepů

$H a c k l, H a k l$ - příjmení z názvů řemeslníků pracujících se dřevem: Baumhäckel = drvoštěp

Sager - ze Säge = pila, v bavorsko-rakouských nářečích nebývá u př́ijmení přehláska - pilař (nebo ze středohornoněmecky sager $=$ žvanil)

Schreiner, Šrejnr, Šrajner - př́ijmení z názvů řemeslníků pracujících se dřevem: střrhněm. schrîn, schrîner = truhláŕ; toto apelativum se i dnes užívá v hornoněmeckém území, mimo jiné také v Bavorsku

Schüss - zkrácená podoba apelativa Schüsselmacher = ten, kdo vyrábí mísy

Steinbrenne - příjmení ze složeného názvu povolání, pro něž bylo př́íznačné pálení; jde o základ -brenner

Tischler, Tišler - z názvů řemeslníků pracujících se dřevem: Tischler = truhlář

Trégler, Trégl - př́ijmení z názvů řemeslníků pracujících se dřevem: střhněm. troc $=$ necky, rakev, troky ${ }^{5}$ (nebo př́jmení z názvů pracovníků v dopravě, deminutivum: střhněm. trage $=$ nosič)

Vágner, Wagner, Wágner - z názvů řemeslníků pracujících se dřevem: Wagner = kolář

Zimmer - z Zimmerer: redukce základu zakončeného na -er: středohornoněmecky zimmer = stavební dříví, budova nebo z názvů řemeslníků pracujících se dřevem

Zimmerer $=$ tesař nebo příjmení z názvů budov a jejich částí, místností: středohornoněmecky zimmer, zimber $=$ stavení, byt

Zimmerhackel - deminutivum ze střhněm. zimberhacke $=$ tesařská sekera, Zimmerhackel $=$ dřevorubec, který těží stavební dříví

Zimmermann - př́ijmení z názvu povolání odvozené pomocí komponentu -mann; jde o starý typ tvoření př́ijmení $\mathrm{z}$ názvů řemeslníků pracujících se dřevem; středohornoněmecky zimmer, zimer $=$ stavební dříví, výdřeva v dolech, Zimmermann $=$ tesař

Také motivace př́jmení Faktor je areálově příznaková. Toto jméno převzaté původně z latiny se do češtiny dostalo přes němčinu ve významu ,Geschäftsvorsteher ${ }^{6}$ [13: 178] a v českém prostředí bylo užíváno především ve vorařském slangu, tzn. v profesi, která byla od středověku až téměř do poloviny 20 . století pro jižní Čechy typická. Zde měl výraz faktor význam ,vedoucí' nebo ,dohlížitel nad voroplavbou'. [17]

Podobně je tomu také u př́imení Flossmann - z názvů řemeslníků pracujících na vodě: střhněm. vlözmann = Flößer ,vorař‘ [14: 251] nebo u prř́jmení Fischer, Fišer - z označení rybářù: Fischer = rybáŕ.

\footnotetext{
${ }^{5} \mathrm{Na}$ Šumavě, v oblasti zkoumaného areálu, označovala střední a starší generace obyvatel ještě ve druhé polovině 20. století necky výrazem (germanismem) troky.
} 
c) Třetí nejpočetněji zastoupený sémanticko-motivační typ německých příjmení u Čechů představují prŕíjmení utvořená $\mathrm{z}$ antroponym, tzn. $\mathrm{z}$ osobních jmen.

$\mathrm{V}$ našem materiálu byla $\mathrm{v}$ tomto typu nejfrekventovanější podskupinou př́íjmení utvořená z částí osobních jmen a $\mathbf{z}$ hypokoristik (slovo domácké, mazlivé, přezdívkové). A je samozřejmé, že motivujícími základy byla jména německá, např́íklad:

Francl - deminutivum, jméno zdrobnělé, tvořené př́íponou $-l$ z hypokoristika, tj. domácké německé podoby křestního jména Franz < z latinského jména osobního Franziskus

Hanzal, Hansal - př́imení odvozené z hypokoristika Hans př́ponou -al; tato př́ípona je variantou prrípony -el, která se vyskytuje v bavorsko-rakouských nářečích; přípona -al vyjadřuje vyšší stupeň zdrobnění než prrípona - $e l$; př́pona -al se vyskytovala na západním území nářečí jihomoravských, na Šumavě a na Chebsku

Hanzel, Hanzl, Hanžel, Hanžl - příjmení odvozené příponou -el z konce jména Johann

Lexa - příjmení utvořené z části osobního jména Alexius; J. Beneš [3: 129] v odkazu na M. Gottschalda [11] uvádí, že ve jménech z oblasti rakousko-bavorských nářečí, která končí koncovkou - $a$ a nejsou slovanského původu, jde o grafické zachycení př́ípony er jako -a, např. Lexa $<$ Lexer $<$ Alexius

Volf, Wolf - příjmení ze začátku osobních jmen Wolfhard, Wolfram, v českých zemích ze zdomácnělého Wolfgang (nebo př́ijmení z názvů šelem: Wolf $=$ vlk či př́ijmení z přezdívky pro samotářského a zlého nebo hltavého člověka; též podle domovního znamení)

Velmi početnou podskupinu představují také německá př́ijmení, která jsou utvořena z různých typů složených germánských jmen. Jako př́íklad uvádíme:

Abert, Abrt - adal = ušlechtilý rod, beracht, berht = skvělý; v Bavorsku je řada místních jmen S určovací částicí Alberts-. [12: 89]

Fridrich, Frydrich - př́ijmení ze složených germánských osobních jmen se základem rïchi = panovník + druhá složka kompozita fridu = ochrana

Kepert, Keppert, Geppert, Gebert, Keprta - 1. př́imení z německých osobních jmen se změnou -hart > -ert nebo z Gebhart; 2. př́ijmení z německých osobních jmen s podobou -rt místo - ert: $\mathrm{z}$ Kábrt; 3. v případě jména Keprta přistupuje k německým př́ijmením Čechů tvořených z osobních a křestních jmen česká koncovka -a: Gebhart $+-a$

Postl - příjmení z německých osobních jmen se změnou -olt > -elt: z Possolt > Posselt: bôse = chlapec; koncové -elt vyslovovali Němci a starší česká generace jako [-lt] nebo př́ijmení zdrobnělé ze středu jména Sebastian

Sipl - příjmení z německých osobních jmen se změnou -bald > -elt > -el/-l: ze Sigibald

Walter, Waltr - př́jmení ze složených germánských osobních jmen se základem -her + wald= vládnout

Werner - prŕíjmení ze složených germánských osobních jmen se základem -her + warin $=$ bojovný

I další sémanticko-motivační typy jsou v našem materiálu zastoupeny četnými př́imeními německého původu. Skupinu př́jmení utvořených z apelativ vztahujících se ke člověku zde reprezentují zejména př́imení utvořená z označení věku a př́ibuzenských vztahů (Bubrle, Kindl/Kyndl, Mann), dále př́ijmení utvořená z názvů tělesných a dušeních vlastností a stavů (Engst, Froyda, Gloc/Kloc) a také př́ijmení z pojmenování částí těla (Beina, Fliegl, Flígl). 
Rovněž prŕjimení utvořená $\mathrm{z}$ apelativ vztahujících se $\mathrm{k}$ přírodě jsou častá (Cais/Cajs, Gaier/Geier, Blüml, Flídr). Méně frekventovaná jsou německá př́ijmení utvořená z jiných slovních druhů než substantiv, zejména z adjektiv (Gross/Gros, Kurz, Lang, Fejgl, Śpeta). Početně nejméně jsou zastoupena př́jmení utvořená ze sloves (Šlemr).

\section{$3 \quad$ Regionální výskyt německých př́ijmení}

Při zkoumání německých př́ijmení a př́ijmení německého původu jsme rovněž zjistili, že některá tato př́ijmení se vyskytují převážně v regionu jižních Čech. To platí například pro vlastní jméno Talafous. Př́́jmení bylo utvořeno z apelativa označujícího končetinu, konkrétně nohu. Vzniklo z něm. Tallafu $\beta$, v první části kompozita je nářeční tvar spisovného Teller = talír̆, ve druhé části substantivum $F u \beta=$ noha; Tallafu $\beta$ tedy označuje znetvořenou nohu. [5: 296] Př́jmení Talafous se přitom ve vyšším počtu vyskytuje pouze v Písku a ve Strakonicích, o něco méně běžné je také $v$ Prachaticích. $V$ dalších městech republiky je zastoupeno jen zcela ojediněle.

Podobně je tomu také u př́ijmení Plojhar. O tomto př́ijmení M. Ederová [18: 112-113] uvádí, že se v německých antroponomických slovnících nevyskytuje a není dohledatelné ani v lexikonu DUDEN [12] či v digitálním slovníku př́ijmení DFD [19]. Server Namespedia [20] uvádí pouze několik málo výskytů v Rakousku (u českých hranic). V České republice je př́ijmení Plojhar silně regionálně omezené a mimo jižní Čechy a speciálně mimo České Budějovice se téměř neužívá.

O př́ijmení Klomfar pak táž autorka [18] konstatuje, že německé slovníky vlastních jmen toto jméno neznají a internetová databáze Namespedia zaznamenává pouze výskyt v Rakousku, př́značně právě v oblastech hraničících s jižními Čechami.

Totéž platí například i pro příjmení Schaffelhofer. Jméno se vyskytuje téměř výlučně v Českých Budějovicích a Trhových Svinech (v Českých Budějovicích žije 56 nositelů tohoto jména z 81 v celé České republice).

Zajímavé je také př́ijmení Fencl. Představuje graficky nejdokonaleji počeštěnou podobu rodného jména Wenzel, tedy německé varianty českého jména Václav. Sv. Václav je hlavním patronem českých zemí, resp. hlavním světcem či identifikační figurou novodobého národa, a německá podoba jeho jména zakonzervovaná v př́ijmení Fencl odráží dřivější intenzivní soužití obou etnických skupin na jednom území. Výskyt př́ijmení Fencl v České republice není omezen pouze na jihočeský region, směrem k česko-německému příhraničí se ovšem počet jeho nositelů výrazně zvyšuje. I v Německu lze mluvit o areálově specifickém výskytu v oblasti Bavorska. [18: 117-118]

Jako další, pro jihočeský region typická př́ijmení můžeme uvést např́iklad jména Liebl, Krautsieder (pouze v Prachaticích), Essl (pouze Český Krumlov, České Budějovice), Kissling (pouze Prachatice), Hamberger (především v Českých Budějovicích, Prachaticích a v Trhových Svinech), Sixl nebo Pouzar. Toto poslední př́ijmení je zcela specifickým př́padem - v německých antroponomických slovnících se vůbec nevyskytuje. Ani jeho varianta Pfauser není dohledatelná v lexikonu DUDEN [12] ani v digitálním slovníku př́ijmení DFD, server Namespedia uvádí jen několik málo výskytů v Rakousku (u českých hranic). V České republice je výskyt př́ijmení Pouzar silně regionálně omezený a mimo jižní Čechy a speciálně mimo České Budějovice jej téměř nelze zaznamenat. [18: 118]

Některá německá př́ijmení z užívání na území České republiky v průběhu 20. století zcela vymizela. Zaznamenat je lze v oblasti jihočeského regionu ještě ve dvacátých a čtyřicátých letech 20. století, v průběhu padesátých let ale zcela mizí. Jsou to například př́ijmení uživaná hlavně ve Volarech a v Prachaticích, naprríklad Brüller, Ferner, Freismuth, Freibichler, 
Gälber, Galner, Gauger, Goschler, Grabl, Grohs, Gugl, Handschel, Kiesslich, Kiseneier, Kolmberg, Kraser, Linzmeier, Sauheitl, Sittel, Kössel, Eichtnecker, Ewinkler, Haselstesinger, Krautsieder, Mutzenbauer, Praxl, Thunitgut a mnoho dalších.

$\mathrm{Z}$ uvedeného, byt' stručného dokladu regionálně se vyskytujících příjmení německého původu je zřejmé, že jak dřívější soužití českého a německého etnika v př́hraniční oblasti jižních Čech, tak i důsledky poválečného odsunu německého obyvatelstva $z$ tohoto regionu lze $\mathrm{v}$ lingvistice, konkrétně v antroponomastice (ale též v toponomastice), doložit ještě i dnes.

\section{Závěr}

Jak vyplývá z uvedených analýz, historické kontakty etnických Němců s českých obyvatelstvem v př́hraniční oblasti jižních Čech dokládají v zaznamenaném materiálu hlavně př́ijmení odvozená z toponym, konkrétně ze jmen místních. Ta poukazují převážně na bavorský, př́padně na rakouský původ německých obyvatel jihočeského regionu. Motivací pro tato př́ijmení byly $\mathrm{v}$ celé řadě př́padů názvy měst, vesnic a osad ležících $\mathrm{v}$ Bavorsku nebo Rakousku, např́iklad Blumauer, Brandtne, Brander, Bruckner, Brukner, Eichner, Fakenberg, Friedberger, Gaier, Keier, Kajer, Grillinger, Grabmüller, Grill, Grubner atd. (viz výše).

Početně velmi obsáhlá skupina německých př́ijmení v našem korpusu je motivována také názvy povolání a názvy řemesel a řemeslníků. Jak jsme již uvedli, jde většinou o řemeslníky a řemesla zabývající se prací se dřevem, tedy činností typickou pro obyvatele hustě zalesněných oblastí české Šumavy a Bavorského lesa. Např́íklad Bender $<$ Binder $=$ bednár̆, Hackl, Hakl < Baumhäckel = drvoštěp, Schreiner, Šrejnr, Šrajner $<$ schrîn, schrîner $=$ truhlár atd.

Bavorský původ německých obyvatel jižních Čech dokládají i některé jazykové znaky. Je to např́íklad hlásková změna $w>b$ charakteristsickápro bavorské dialekty ve jméně Bébr< z Weber $=$ tkadlec, hlásková změna $\ddot{u}>\ddot{o}$ rovněž typická pro bavorská nářečí ve jméně Pešl, Pöschl <Püschel = na Šumavě 'svazek zeleniny' nebo bavorská nářeční změna $\ddot{o}>i$ a koncové $-a$ místo -er v koncovce př́ímení Binka $<\mathrm{z}$ Böhmer. Je zajímavé, že s jinými než bavorskými hláskovými změnami jsme se v analyzovaných př́ijmeních nesetkali.

Uvedené závěry $\mathrm{z}$ analýz německých př́ijmení zaznamenaných na základě archivních dokumentů potvrzují, že kontakty mezi obyvateli jihočeského a bavorského pohraničí, př́padně i jejich soužití, byly v minulosti běžné a dlouhodobé. Zároveň dokládají, že jazyk, v tomto př́padě vlastní jména osobní, př́ijmení, reflektují historii, tradici i kulturu regionu, v němž jsou dodnes užívána.

\section{Literatura}

[1] MICKO, MICKO, H.: Die Mundart von Wadetstift im Böhmerwald..Lautlehre, Reichenberg. 1930.

[2] KUBITSCHEK, R.: Die Mundarten des Böhmerwaldes. Nakladatelství neuvedeno, Plzeň, 1927.

[3] BENEŠ, J.: Německá př́jmení u Čechů. I. a II. díl. Rejstř́iky zpracovala Marie Nováková. Univerzita J. E. Purkyně v Ústí nad Labem, Ústí nad Labem, 1/1998, 2/1998. ISBN 80-7044-212-3.

[4] SCHWARZ, E.: Jazyk německý na území ČSR. In: Československá vlastivěda. Díl III. Jazyk. „Sfinx““- B. Janda, Praha, 1934. 
[5] JAKLOVÁ, A.: Jazyková situace v př́hraniční oblasti jižních Čech. In: Jaklová, A.; Harnisch, R. (eds.), Od tradice k budoucnosti. Jazykově-literárni dědictví Východního Bavorska a jižních Čech jako fokus univerzitní spolupráce. Nakladatelství ARSCI, Praha, 2019, s. 13-68. ISBN 978-80-7420-057-1.

[6] NEWERKLA, S. M.: Areály jazykového kontaktu ve střední Evropě a německo-český mikroareál ve východním Rakousku. Slovo a slovesnost. 2007, Vol. 68, s. 271-286.

[7] KNAPPOVÁ, M.: O systému př́ijmení užívaných v českých zemích. In: Hasil, J. (ed.), Přednášky z 37. a 38. běhu LŠSS. Univerzita Karlova, Praha, 1995, s. 95-102.

[8] KNAPPOVÁ, M.: Naše a cizí př́jmení v současné češtině. AZ KORT, Liberec, 2008. ISBN 80-238-8173-6.

[9] MOLDANOVÁ, Dobrava. Naše př́imení. Agentura Praha, Pankrác, 2015. ISBN 97880-86781-26-6.

[10] MATÚŠOVÁ, J.: Německá vlastní jména v češtině. Nakladatelství Lidové noviny, Praha, 2015. ISBN 978-80-7422-369-3.

[11] SCHWARZ, E.: Sudetendeutsche Familiennamen aus vorhussitischer Zeit (Ost Mitteleuropa in Vergangenheit und Gegenwart 3). Böhlau, Köln, 1957.

[12] KOHLHEIMOVÁ, R.; KOHLHEIM, V.: DUDEN: Lexikon der Familiennamen. Herkunft und Bedeutung von 20000 Nachnamen. Bibliographisches Institut - F. A. Brockhaus AG, Mannheim, 2005. ISBN 3-411-70852-2.

[13] GOTTSCHALD, M.: Deutsche Namenkunde. Mit einer Einführung in die Familienkunde von Rudolf Schützeichel. 6., durchgesehene und bibliographisch aktualisierte Auflage. Walter de Gruyter, Berlin-New York, 2006. ISBN 3-11-018032-4.

[14] HORNUNG, M.: Lexikon österreichischer Familiennamen. Verlag Niederösterreichisches Pressehaus, St. Pölten - Wien, 1989. ISBN 3-85326-854-4.

[15] KUNZE, K.: dtv-Atlas Namenkunde: Vor- und Familiennamen im deutschen Sprachgebiet. Deutscher Taschenbuch Verlag, München, 1998. ISBN 3-423-03234-0.

[16] KLAUSMANN, H.: Atlas der Familiennamen von Bayern. Jan Thorbecke Verlag der Schwabenverlag AG, Ostfildern, 2009. ISBN 978-3-7995-0225-2.

[17] JAKLOVÁ, A.: Voroplavba a vorařský slang v jižních Čechách. In: Jaklová, A. et al. (eds.), Jazyk a řeč jihočeského regionu III. Pedagogická fakulta JU, České Budějovice, 1994, s. 49-70.

[18] EDEROVÁ, M.: Př́íjmení německého původu v Českých Budějovicích ve 20. století. In: Jaklová, A.; Harnisch, R. (eds.), Od tradice k budoucnosti. Jazykově-literární dédictví Východního Bavorska a jižních Čech jako fokus univerzitní spolupráce. Nakladatelství ARSCI, Praha, 2019, pp. 69-152. ISBN 978-80-7420-057-1.

[19] Digitales Familiennamenwörterbuch Deutschlands (DFD). Wörterbuch. [online]. [cit. 2021-02-2]. Dostupné z WWW: http://www.namenforschung.net/dfd/woerterbuch/liste/

[20] NAMESPEDIA: Encyklopedie jmen - statistiky, etymologie, přesmyčky, slavní lidé, rýmy. [online]. [cit. 2021-02-10]. Dostupné z: http://www.namespedia.com

[21] MALAČKA, O: Kde jsme. [online]. [cit. 2021-02-15]. Dostupné z WWW: https://www.kdejsme.czl

prof. PhDr. Alena Jaklová, CSc. 


\section{GERMAN SURNAMES IN THE BORDER AREA OF SOUTH BOHEMIA AND THEIR SEMANTIC-MOTIVATIONAL TYPES}

This article analyses German surnames from the point of view of their motivation and classification into respective semantic-motivational types. The analysis is based on a corpus of data compiled at the beginning of the $21^{\text {st }}$ century from the archive records containing surnames of inhabitants of the towns of Prachatice, Volary, Vimperk and Kašperské Hory. All of these towns are situated close to the German border and, until the mid-1940s, had predominantly been inhabited by German population. The final section of the article identifies the most frequent semantic-motivational types of German surnames currently used by Czechs in the area explored. The article also explains the etymology and motivation of these surnames in relation to the history of the region and to ethnic groups inhabiting the area since the Middle Ages.

\section{DEUTSCHE FAMILIENNAMEN IM SÜDBÖHMISCHEN GRENZRAUM UND IHRE SEMANTISCHE TYPOLOGIE}

Der vorliegende Beitrag beschäftigt sich mit der Analyse deutscher Familiennamen hinsichtlich ihrer semantischen Motivierung und mit ihrer anschließenden Klassifikation. Das der Analyse zugrunde gelegte Materialkorpus ging aus einer zu Beginn des 21. Jahrhunderts erfolgten Auswertung von Archivmaterialien hervor und umfasst Familiennamen der Einwohner von Prachatitz, Wallern, Winterberg und Bergreichenstein. Diese im bayerischböhmischen Grenzraum liegenden Städte waren bis Mitte der 1940er Jahre vorwiegend deutsch besiedelt. Im Beitrag werden die häufigsten, hinsichtlich ihrer semantischen Motivierung zu unterscheidenden Typen der dort gegenwärtig vorkommenden deutschen Familiennamen vorgestellt. Gleichzeitig lassen sich deren Etymologie und Motivierung im Bezug zur Geschichte der Region und den in diesem Raum seit dem Mittelalter ansässigen Volksgruppen aufzeigen.

\section{NIEMIECKIE NAZWISKA NA PRZYGRANICZNYM OBSZARZE POŁUDNIOWYCH CZECH I ICH TYPY MOTYWACJI SEMANTYCZNEJ}

Przedmiotem artykułu są analizy niemieckich nazwisk przeprowadzone w aspekcie motywacji oraz ich klasyfikacja wg typów motywacji semantycznej. Analizy oparto na zbiorze materiałów, opracowanym na początku XXI wieku na podstawie badań materiałów archiwalnych odnotowujących nazwiska mieszkańców gmin Prachatice, Volary, Vimperk i Kašperské Hory. To miasta leżące $w$ pobliżu granicy z Niemcami, które do połowy lat czterdziestych XX wieku zamieszkane były przeważnie przez ludność niemiecką. W zakończeniu artykułu wskazano najczęściej występujące typy motywacji semantycznej obecnych niemieckich nazwisk Czechów używanych na badanym obszarze. Ponadto wyjaśniono etymologię i motywację tych nazwisk w odniesieniu do historii regionu i grup etnicznych, które zamieszkiwały te tereny już od średniowiecza. 